\title{
Response of quinoa crop for water stress and planting date in the middle Egypt
}

\author{
Abdel-Rheem, H.A. ${ }^{1}$ Abdrabbo A. A. Aboukheira ${ }^{2}$ and Nadia, M. A. Eisa ${ }^{3}$ \\ $1 \& 2$ - Water Management Research Institute, National Water Research Center, Egypt \\ 3- Department of Crop Intensification Research, Field Crops Research Institute, Agricultural \\ Research Center, Giza, Egypt
}

\begin{abstract}
Two field experiments were carried out at Mallawy Experiment Station, El-Minia Governorate in the Middle Egypt during the growing winter seasons of 2012/2013 and 2013/2014 to study the effect of water stress and planting date on actual crop water requirements, crop coefficient, and yield of Quinoa as an alternative crop for food security in Egypt. In addition, this study aimed at evaluating and comparing the potential evapotranspiration $\left(\mathrm{ET}_{\mathrm{P}}\right)$ equations for estimating actual crop water requirements under El- Minia Governorate conditions.

The experiment was carried out on three treatments of planting dates (A) and two irrigation regimes (B) with four replications; also, the experiment was implemented in a split plot design. Sowing dates treatments were November $25^{\text {th }}$, December $25^{\text {th }}$ and January $25^{\text {th }}$. The irrigation regime treatments were irrigation at a depletion of $20 \%$ from A.W. (b1), irrigation at a depletion of $40 \%$ from A.W. (b2), and irrigation at a depletion of $60 \%$ from A.W. $\left(b_{3}\right)$. Sowing dates were distributed randomly in the main plots, while irrigation regime treatments were distributed in the sub- plots.

The results indicated that the actual water consumptive use from planting until harvest were $22.62,21.41$ and $21.47\left(\mathrm{~cm} /\right.$ season) for treatments $\mathrm{A}_{1}, \mathrm{~A}_{2}$ and $\mathrm{A}_{3}$, respectively under all different irrigation regimes. The results indicated that from the view point of the highest values of total yield $(\mathrm{t} / \mathrm{fed})$, they were obtained from treatment irrigation at $60 \%$ depletion of valuable water $\left(\mathrm{b}_{3}\right)$ and sowing on $25^{\text {th }}$ November $\left(\mathrm{A}_{1}\right)(1.06$ ton/fed.)

Monthly reference potential evapotranspiration $\left(\mathrm{ET}_{\mathrm{o}}\right)$ for El-Minia Governorate, the Middle Egypt, was calculated using the modified Penman, modified Blaney \& Criddle and Pan Evaporation method. Average $(\mathrm{Kc})$ values of the three methods for different treatments were calculated to come up with accurate one value representing the $(\mathrm{Kc})$. The average values of $\mathrm{Kc}$ for $\mathrm{A}_{1}, \mathrm{~A}_{2}$ and $\mathrm{A}_{3}$ were 0.47 , 0.37 and 0.29 under irrigation regime $\left(b_{1}\right)$, respectively, while its values for the same treatments under irrigation regime $\mathrm{b}_{2}$ were $0.48,0.45$ and 0.35 , respectively, and its values for the same treatments under irrigation regime $\left(b_{3}\right)$ were $0.53,0.41$ and 0.36 , respectively. The results also indicted that modified Blaney \& Criddle equation achieved the highest average value for potential evapotranspiration $\mathrm{ET}_{\mathrm{P}}(629.41 \mathrm{~mm} / \mathrm{season})$, while the Pan Evaporation method recorded the lowest average value $(504.12 \mathrm{~mm} /$ season) in the two winter seasons.

The average values of potential evapotranspiration $\left(\mathrm{ET}_{\mathrm{P}}\right)$ by modified penman were nearest to the scientific literature average values $(+2.79 \%)$, while the farthest values to scientific literature average ones were obtained by modified Blaney \& Criddle and Pan Evaporation method $+11.18 \%$ and $-12.64 \%$, respectively.

In conclusion, it is recommended that irrigation of quinoa plants with depletion $60 \%$ of available water in the upper $60 \mathrm{~cm}$ layer of soil (40 days apart between each two irrigation events) with cultivation date of $25 / 11$ in order to produce high yield under the experiment conditions. On the other hand, this study indicated that the average values of potential evapotranspiration (ETcal ) by modified Penman was nearest to the actual water consumptive use of quinoa crop. Therefore, modified Penman equation is recommended for calculating the potential evapotranspiration of quinoa under the Middle Egypt conditions.
\end{abstract}

Key words: Quinoa crop, water stress, planting date , Middle Egypt 
Abdel-Rheem, H.A. et al.

INTRODUCTION

Water is fast becoming an economically scare resource in many areas of the world especially in arid and semi-arid regions. In Egypt, there are many plants for increasing cultivable land and agriculture production to overcome problems of the food security soil soil moisture is one of the most important factors which influence the yield and quality of crops as it affects the chemical, biological and physical conditions of soil. Available water in soil is essential for the life and function of plants. Water is necessary for growth, nutrient , absorption, transpiration, biological reactions and many other life activities. therefore, water requirements should be achieved to reach a well controlled scientific use of water. In all countries, all over the world, water is considered a limiting factors in agricultural expansion . The various phases of water consumption and direct use by human begins, animal, industry and irrigation .

As population increases, greater competition among the various phases makes conservation of water imperative. Agriculture is by no means the major competitor for water consumption. Adding too much or too little water may cause a serious damage for crops, water requirements must be carefully determined. In order to achieve this goal, the evapotranspiration (consumptive use of water) for each crop growing in various soil types under different climatologically conditions, must be calculated so as to evaluate the water regimes . this could be aided by the determination of the periodical evapotranspiration rates for each crop and define the most critical periods in which a crop either requires maximum or minimum amounts of water. Measuring or calculating evapotranspiration rate could be achieved by many ways such as soil moisture depletion method and using the meteorological data throughout the growth seasons.The late method leads to evaluate an imperial constant, for specific vegetation grown in particular location, which can be used afterwards as an index for direct calculation of evapotranspiration. In addition, salinity is considered as main major problem in agriculture, particularly because saline soils are found primarily in arid regions where draught, extreme temperatures, and nutrient deficiency go hand in hand, and where scarce precipitation and high evaporation hinder a leaching out of the salts that accumulate in the upper soil layers .It is estimated that between 340 and as much as 950 billion squares kilometers, equivalent to about $20 \%$ of the arid and semiarid soils of the world, or $6 \%$ of the world land area are saline. There is an increase in salinization due to irrigation , which is estimated to affect $50 \%$ of irrigated land (Jacobsen et al., 2001). There are only few crops can be grown under marginal and extreme saline, dry and cold areas, quinoa is one of them (Jacobson and Mukica, 2001). In Europe, quinoa was suggested to be as a break crop between cereal crops and after potato crops. When grown in areas to which it is best adapted, it should be able to compete with cereals in both human diets and animal rations (Galway,1992) .So far, the results regarding quinoa as a drought resistant crop of high nutritive quality, which can be grown on poor, infertile soils, seem promising (Jacobsen and Stolen,1993). It was suggested to be an important new for Pakistan agriculture, providing highly nutritive and versatile food products for the population and a new raw material for the industry. In particular, it could be cultivated in many of the marginal environments afflicated by drought or salinity stress, which currently suffer from very low productivity (Jacobsen et al., 2002) . Environmental extreme conditions of Southem America ,Pakistan and Egypt deserts tend to participate similar features (both of them face draught and salinity problems side by side), so that, quinoa could be suggested as an attractive alternative crop for the arid and semiarid regions, where water deficiency and salinity have been recognized as major agricultural problems (Prado et al., 2000). Many investigators showed in this connection Koziol (1993) showed that Quinoa (Chenopodium quinoa) grain contains 1.8-9.5\% oil on a FW basis. The oil is concentrated inn the germ, which represents $25-30 \%$ of the grain weight. The germ can be removed by polishing to give a fraction containing about $19 \%$ oil. Geel 
Response of quinoa crop for water stress and planting date in the middle Egypt

(1997) showed that Seed yields ranged from 1.5 to 5 ton ha $^{-1}$. Low yields were caused by low total production, a low harvest index in late -maturing cultivars and seed shedding during ripening. Nunez et al. (1997) showed that exposing Quinoa (Chenophodium quinoa) cv. Kancolla plants to water stress at branching, flowing or grain filling, affected on leaf water potential, stomatal conductance, photosynthesis, osmotic potential, turgor pressure and leaf water content showed that quinoas drought resistant . Koyro and Eisa (2008) reported that Plant growth and total seed yield were all significantly reduced in the presence of salinity. They also demonstrated that a highly protected seed interior leading to a high salinity resistance of quinoa seeds . Martinez el al. (2009) evaluated grain yield of two quinoa Inadraces (Don Javi and Palmilla) from lowlands of Central Chile $\left(34^{\circ} \mathrm{C}\right)$ during two seasons (2005 and 2006), they showed that Yield of 2006 harvesting season ( 7 ton $^{-1}{ }^{-1}$ ) was higher than that of the previous seasons $\left(5.5\right.$ ton $\left.\mathrm{ha}^{-1}\right)$, they suggested that better yields needs additional irrigation and addition of organic matter. Rijtema (1966) pointed out that in order to calculated the evapotranspiration from certain crop, the potential value must be multiplied by crop coefficient (K.c). He also declared may methods calculate the potential evapotranspiriation and some of these methods or formulas gave reasonable accuracy under certain climatological conditions. Others methods agree only with the observed values of correction for time log and wind speed . Doorrenhbos and puritt (1975) stated that BlaneyCriddle method may be used when temperature data were the only available measured weather data. They reported that the radition method was more reliable than the presented Blaney \& Criddle approach. In equatorial zone, on small island or at high altitudes, the radiation method might be more reliable even if measured sunshine or cloudless data were not available. Solar radiation maps were prepared for most locations in the world and they provided the necessary solar radiation data. He also pointed out crop water requirements are normally expressed by the rate of evapotanspiration (ET) in $\mathrm{mm} / \mathrm{day}$ or $\mathrm{mm} /$ period. The level of ET has been shown to be related to evaporative demand off air which could be expressed as reference evapotranspiration and added calculated the crop evapotranspiration by using the following formula: $\mathrm{ETc}=\mathrm{Kc} \times \mathrm{ETo}$

Where :

$\mathrm{ETc}=$ Crop evapotranspiration

$\mathrm{Kc}=$ Crop coefficient .

$\mathrm{ETo}=$ Reference crop evapotranspiration

They added that the determination of crop coefficient ( Kc) could be used as reference crop evapotranspiration (ETo) to maximum crop evapotranspiration when water supply full met water requirements of the crop. The objective of the resent work was evaluated the effect of sowing date and irrigation regime on water applied, water consumptive use, crop coefficient and, yield for Quinoa .

\section{MATERIALS AND METHODS}

Two field experiments were carried out for two winter seasons of 2012/ 2013 and 2013 / 2014 seasons, at Mallawy, Water Requirements Research Station - El Minia Governorate; Water Management Research Institute- National . Water Research Center. The present research was carried out to study the effect of sowing dates and irrigation regime on water applied, water consumptive use, crop coefficient and yield of Quinoa crop .

The experiments included three treatments of sowing dates (A) and two regime of irrigation (B) with four replicated so that the experiment was arranged in a split plot design . Sowing dates treatments were $25^{\text {th }}$ November, $25^{\text {st }}$ December and $25^{\text {th }}$ January. The irrigation regime treatments were irrigate at a depletion of $20 \%$ from A.W. $\left(b_{1}\right)$, irrigate at a depletion 
Abdel-Rheem, H.A. et al.

of $40 \%$ from A.W. $\left(b_{2}\right)$ and irrigate at a depletion of $60 \%$ from A.W. $\left(b_{3}\right)$. Sowing dates were distributed at random in the main plots. While irrigation regime treatments were distributed at random in the sub- plots ..Each plot area was $12 \mathrm{~m}^{2}$ consisted of 4 rows with 5 $\mathrm{m}$ length, and the pacing was $0.6 \mathrm{~m}$ bwtween rows, and both sides of row were cultivated and sowing rate was $3 \mathrm{gm}$ per $5 \mathrm{~m}$ equal about 75 plant $\mathrm{m}^{-2}\left(4.2 \mathrm{~kg} \mathrm{fed}^{-1}\right.$, feddan $\left.=4200 \mathrm{~m}^{2}\right)$ and a sowing depth of $2 \mathrm{~cm}$.

\section{Soil analyses :}

Soil analyses showed that the experimental soil was silt clay loam containing ( 0.11 and $0.10 \%$ of total $\mathrm{N}),(11.8$ and $11.0 \mathrm{ppm}$ available $\mathrm{P})$, and ( 0.44 and $0.40 \mathrm{meq} / 100 \mathrm{~g}$ soil $\mathrm{K})$ with $\mathrm{pH} 8.10$, in both studied seasons, respectively. Also same the physical characteristic as shown in Table (1). Organic and Calcium super phosphate $(15.5 \%$ of $\left.\mathrm{P}_{2} \mathrm{O}_{5}\right)$.Fertilizers were applied fully prior to planting at the rate of $150 \mathrm{~kg} \mathrm{fed}^{-1}$. Urea $(46.5 \%$ $\mathrm{N})$ was added at the rate of $150 \mathrm{~kg} \mathrm{fed}^{-1}$ and Potassium Sulphate $\left(50 \% \mathrm{~K}_{2} \mathrm{O}\right)$ was added at the rate of $150 \mathrm{~kg} \mathrm{fed}^{-1}$ (Gesinski ., 2006) and (Geel.,1997) .

\section{Climatic condition :}

Some metrological data during the two growing seasons are presented in Table 2 . These data were obtained from metrological Mallawy Station located at the $279^{-}$latitude and $305^{-}$logtiude and its altitude is about $44 \mathrm{~m}$ above sea levels. These data are used to get potential evapotranspination $\mathrm{mm} /$ day

by different empirical formula such as modified Panman, modified Blaney \& Criddle and pan method.

\section{Recorded data :}

Soil- water relations

\section{Water Applied}

In both growing seasons, water was measured by using a rectangular sharp crested weir. The discharge was calculated using the following formula :

$\mathbf{Q}=\mathbf{C L H}^{\mathbf{3} / 2} \quad$ (Masoud, 1967)

Where:

Q : The discharge in cubic meters per second.

$\mathrm{L}$ : The length of the crest in meters.

$\mathrm{H}$ : The head in meters.

$\mathrm{C}$ : An empirical coefficient that must be determined from discharge measurements .

\section{Water consumptive use ( CU ) :}

The quantities of consumptive use were calculated for the $60 \mathrm{~cm}$ soil depth which was assumed to be the depth of the root zone as reported by many investigators .

Monthly and seasonal water consumptive use were calculated by the summation of water consumed for the different successive irrigation through the whole growth season. Calculation of $\mathrm{CU}$ was repeated for all irrigation until the harvesting .

Water consumptive use per feddan $\left(4200 \mathrm{~m}^{2}\right)$ can be obtained by the following equation:

\section{$\mathrm{CU}=\left[\left(\theta_{2}-\theta_{1) / 100]} X\left(\right.\right.\right.$ b.d) $X\left(\right.$ depth/100) $X$ Area $\left(4200 \mathrm{~m}^{2}\right)$}

which described by Israelsen and Hansen ( 1962 )

Where :

$\mathrm{CU}=$ Amount of water consumptive use $\left(\mathrm{m}^{3} /\right.$ fed. $)$. 
Response of quinoa crop for water stress and planting date in the middle Egypt

$\theta_{2}=$ Soil moisture content ( $\%$ by weigh) after irrigation .

$\theta_{1}=$ Soil moisture content ( $\%$ by weigh) before the next irrigation

b.d = Bulk density $\left(\mathrm{g} / \mathrm{cm}^{3}\right)$

\section{Potential evapotranspiration ( ET $_{\mathbf{p}}$ ) Modified Penman equation:}

$E T_{p}=c[($ W.Rn + 1-w ) .f (u) .(ea-ed) $]$ mm/day .

Where :

$\mathrm{ET}_{\mathrm{p}=}$ Reference crop evapotranspiration $\mathrm{mm} /$ day .

$\mathrm{W}=$ Temperature - related weighting factor.

$\mathrm{Rn}=$ Net radiation in equivalent evaporation in $\mathrm{mm} /$ day.

$\mathrm{f}(\mathrm{u})=$ Wind-related function.

ed=Saturation vapour pressure of the air in ( $\mathrm{mm}$ bar).

ea $=$ Mean actual vapour pressure of the air in ( $\mathrm{m}$ bar)

=ea $\mathrm{xH}$ mean $/ 100$, in which, $\mathrm{RH}=$ relative humidity .

( ea-ed) $=$ Difference between the saturation vapour pressure at mean air temperature and the mean actual vapour pressure of the air, both in mbar .

$\mathrm{c}=$ Adjustment factor to compensate for the effect of day and night weather conditions.

\section{Modified Blaney \& Criddle equation :}

Blaney and Criddle (1955) observed that the amount of water consumptive used by crop during their growing seasons was closely correlated with means monthly temperature and day light hours .

$\mathrm{ET}_{\mathrm{p}}=\mathrm{C}[\mathrm{P}$ 0.64T +8.13$\left.)\right] \mathrm{mm} / \mathrm{day}$.

Where :

$\mathrm{ET}_{\mathrm{p}}=$ Potential evapotranspiration in $\mathrm{mm} /$ day .

$\mathrm{T}=$ Mean daily temperature in ${ }^{\circ} \mathrm{C}$

$\mathrm{P}=$ Mean daily percentage of total annual daytime hours for given month and latitude .

$\mathrm{C}=$ Adjustment factor which depends on minimum relative humidity , sunshine hours and day time wind estimate .

\section{Pan evaporation method :}

Reference crop evapotranspiration ( $\mathrm{ET}_{\mathrm{p}}$ ) can be obtained from the following equation $\mathrm{ET}_{\mathrm{p}}=\mathrm{KP} . \mathrm{E}_{\mathrm{pan}}(\mathrm{mm} / \mathrm{day})$.

Where :

$\mathrm{K}_{\mathrm{p}}=$ Pan coefficient depends on type of Pan , condition of Humidity, wind speed and speed and pan environmental conditions $(=0.75)$.

\section{Crop Coefficient ( Kc )}

Crop coefficient defined as the ratio between actual crop evapotranspiration $\left(\mathrm{ET}_{\mathrm{a}}\right)$ and potential evapotranspirtaion $\left(\mathrm{ET}_{\mathrm{p}}\right)$ when both are in a large fields, under optimum growing conditions ( FAO , 1977 ). In the experiment the following equation was applied to compute the Kc values: .

$\mathbf{K c}=\mathbf{E T}_{\mathrm{a}} / \mathbf{E} \mathbf{T}_{\mathrm{p}}$ 
Abdel-Rheem, H.A. et al.

Where :

$\mathrm{Kc}=$ Crop coefficient

$\mathrm{ET}_{\mathrm{a}}=$ Actual evapotranspirtation $(\mathrm{mm} /$ day $)$.

$\mathrm{ET}_{\mathrm{p}}=$ potential evapotranspiration calculated by modified Penman $(\mathrm{mm} / \mathrm{day})$.

\section{Statistical analysis :}

Data obtained from experimental treatments were subjected to statistical analysis and treatments means were compared using the L.S.D methods according to Snedecor and Cocharn (1980) .

\section{Total yield (ton/ fed.) :}

\section{RESULTS AND DISCUSSIONS}

Data given in Table (3) showed significant differences in fed at different sowing dates . The highest yield of Quinoa was obtain by sowing Quinoa on $25^{\text {th }}$ November. Data in Table 3 indicated also that yield increased by $20.53 \mathrm{a}$ and $45.08 \%$ by sowing Quinoa crop on $25^{\text {th }}$ November $A_{1}$ compared with sowing it on $25^{\text {th }}$ of December $A_{2}$ and $25^{\text {th }}$ and January $A_{3}$ respectively. This may be due to the higher infection by insects, and diseases in the late sowing on $25^{\text {th }}$ December $A_{2}$ and $25^{\text {th }}$ January $A_{3}$ than sowing $25^{\text {th }} A_{1}$ November.

Data in Table 3 showed also that yield of Quinoa crop was influenced statically by the studied irrigation regime where the yield of Quinoa crop increase by about 36.75 and 7.59under irrigation at a depletion of $60 \%$ from available water $b_{3}$. than $b_{1}$ and $b_{2}$ respectively. Concerning the interaction between the two studied factors, data in Table 3 show that, rom water view point the highest values of total yield (ton / fed ) were obtained from treatment which irrigated at $60 \%$ depletion of A.W and sowing on $25^{\text {th }}$ November $\left(\mathrm{A}_{1} \mathrm{~b}_{3}\right)$ and this treatment was the most superior treatment on this character ( $1.06 \mathrm{ton} / \mathrm{fed}$.) in the both studied seasons This result is line with those reported by Geel (1997), Nunez et al (1997) and Martinez et al . (2009).

\section{Daily, monthly and seasonal actual water consumptive use :}

Daily and monthly actual water consumptive use values were presented in Tables (4 and 5). The obtained indicated that daily water consumptive use increased gradually until reached its maximum values in flowing and milk stage in both seasons which is considered the critical stage period in water demands of com crop. Then, it declined by the end of growing and the water loss is almost due to evaporation from soil surface, while small amount loss by consumptive use. These results are in agreement with those reported by Isrealen and Hasaen (1962). Data in Table 4 show that average quantity of actual water consumptive use (cm / season) from planting until harvest were $21.68,19.40$, and 18.01 for $\mathrm{A} 1, \mathrm{~A} 2, \mathrm{~A} 3 \mathrm{~cm} /$ season under irrigation regime $\left(\mathrm{b}_{1}\right)$, respectively. While , were $22.56,22.11$ and $21.09 \mathrm{~cm} /$ season for treatments sames $A_{1}, A_{2}, A_{3}$, respectively under irrigation regime $\left(b_{2}\right)$ While, were 23.63, $23.09,22.01 \mathrm{~cm} /$ season for treatments sames $\mathrm{A}_{1}, \mathrm{~A}_{2}, \mathrm{~A}_{3}$, respectively under irrigation regime $\left(b_{3}\right)$. Jenerally, results indicate that in Table (5) the actual water consumptive use from planting until harvest were $22.62,21.41$ and $21.47(\mathrm{~cm} / \mathrm{season})$ for treatments $\mathrm{A} 1, \mathrm{~A}_{2}$, and $\mathrm{A}_{3}$ respectively under all different irrigation regime

\section{Potential evapotranspiration $\left(\mathbf{E T}_{\mathrm{p}}\right)$ :}

Data in Table (6) shows that the computed values of daily, monthly and seasonal potential evapotranspiration $(\mathrm{mm} /$ day, $\mathrm{mm} /$ month and $\mathrm{mm} /$ season, respectively) according to modified Penman, modified Balney \& Criddle and pan method for two studied seasons .It can be observed from data in Table 6 that the lowest average of ET $\mathrm{P}$ values (58.02 and $504.20 \mathrm{~cm} / \mathrm{season}$ ) were obtained from modified Panman and pan method, respectively 
Response of quinoa crop for water stress and planting date in the middle Egypt

during both studied seasons. While, the highest average $\mathrm{ET}_{\mathrm{P}}(62.94 \mathrm{~cm} / \mathrm{season})$ was obtained by modified Blany and Criddle during both studied seasons. This due to the estimated factors in these equations. Results in Table 6 shown also that the average values of potential evapotransperation $\left(\mathrm{ET}_{\mathrm{p}}\right)$ by modified penman was nearest to general average values (+ $2.79 \%$ ) while, the farthest values to general average were obtained by pan method and motifed Blany \& Criddle about $(-12.64 \%$ and $+11.18 \%)$, respectively .

It could be noticed that the nearest $\mathrm{ET}_{\mathrm{P}}$ values to the average are those which are obtained form modified Penman while, the farest obtained from the pan method .These results are in agreement with those obtained by Doorenhbos anmd Pruitt (1975) .

\section{Crop coefficient $(\mathrm{Kc})$ :}

Effect of cop characteristics on crop water requirement was indicated by the crop coefficient $(\mathrm{Kc})$ which represent the relationship between reference potential $\left(\mathrm{ET}_{\mathrm{p}}\right)$ and actual crop evapotranspiration (ETa)

Data of crop coefficient for Quinoa crop for each treatment calculated using the actual consumptive use (ETa) and potential evapotranspiration (ETp) $\left(\mathrm{Kc}=\mathrm{ET}_{\mathrm{a}} / \mathrm{ETp}\right)$ using the modified Penman, modified Blaney \& Criddle and pan method. The values of Kc for different treatments are shown in Tables (7, 8 and 9). It is clear that the values of Kc show slight increase with time after planting till reached their peak in formation of flowering and then decreased at the end of growth season. Results show that average Kc for the all treatments were calculated to be $0.47,0.37$ and 0.29 for $A_{1}, A_{2}$ and $A_{3}$ under irrigation regime $\left(b_{1}\right)$, respectively. While, were $0.48,0.45$ and 0.35 for same treatments under irrigation regime $b_{2}$ respectively. While, were $0.53,0.41$ and 0.36 for same treatments under irrigation regime $b_{3}$ respectively. It could be noticed that the nearest values to average $\mathrm{Kc}$ those which calculated by modified Penman while the farthest were by pan method .

\section{The calculated evaotranspiration (ET $\left.\mathbf{T}_{\text {cal. }}\right)$ :}

The calculated evapotranspiration $\left(\mathrm{ET}_{\text {cal. }}\right) \mathrm{mm} / \mathrm{month}, \mathrm{mm} /$ season and $\mathrm{cm} / \mathrm{season}$ ) are shown in Tables 10,11 and 12 for different treatments using the relation $\mathrm{ET}_{\text {cal. }}=\mathrm{Kc}$ average $\mathrm{X} \mathrm{ET}_{\mathrm{p}}$ and its comparison with actual consumptive use $\left(\mathrm{ET}_{\mathrm{a}}\right)$ for different treatments in Tables (13,14 and 15) and Figures 1, 2 and 3). Data in Tables (13,14 and 15) indicated that calculated evapotranspiration $\mathrm{ET}_{\text {cal }}$ ) by modified Penam followed by modified Bleny \& Crridle easily clarify the degree of accuracy for the calculated evapotranspiration as it show that the only values outside the $95 \%$ confidence limits are those of the modified Bley \& Crridle for $A_{1}$ under irrigation regime (20\% depletion of A.W) while, the farthest values outside the $95 \%$ confidence limits for all treatments $A_{1}, A_{2}$ and $A_{3}$, are those of the pan method. So we can recommend this equation (Modified penma) for estimating ET $_{P}$ in Minia region with the average crop coefficient due to the highest accruing for Quinoa crop These results are in agreement with those reported by Rijtema (1966) and Doorenhbos and Pruit (1975) . 
Abdel-Rheem, H.A. et al.

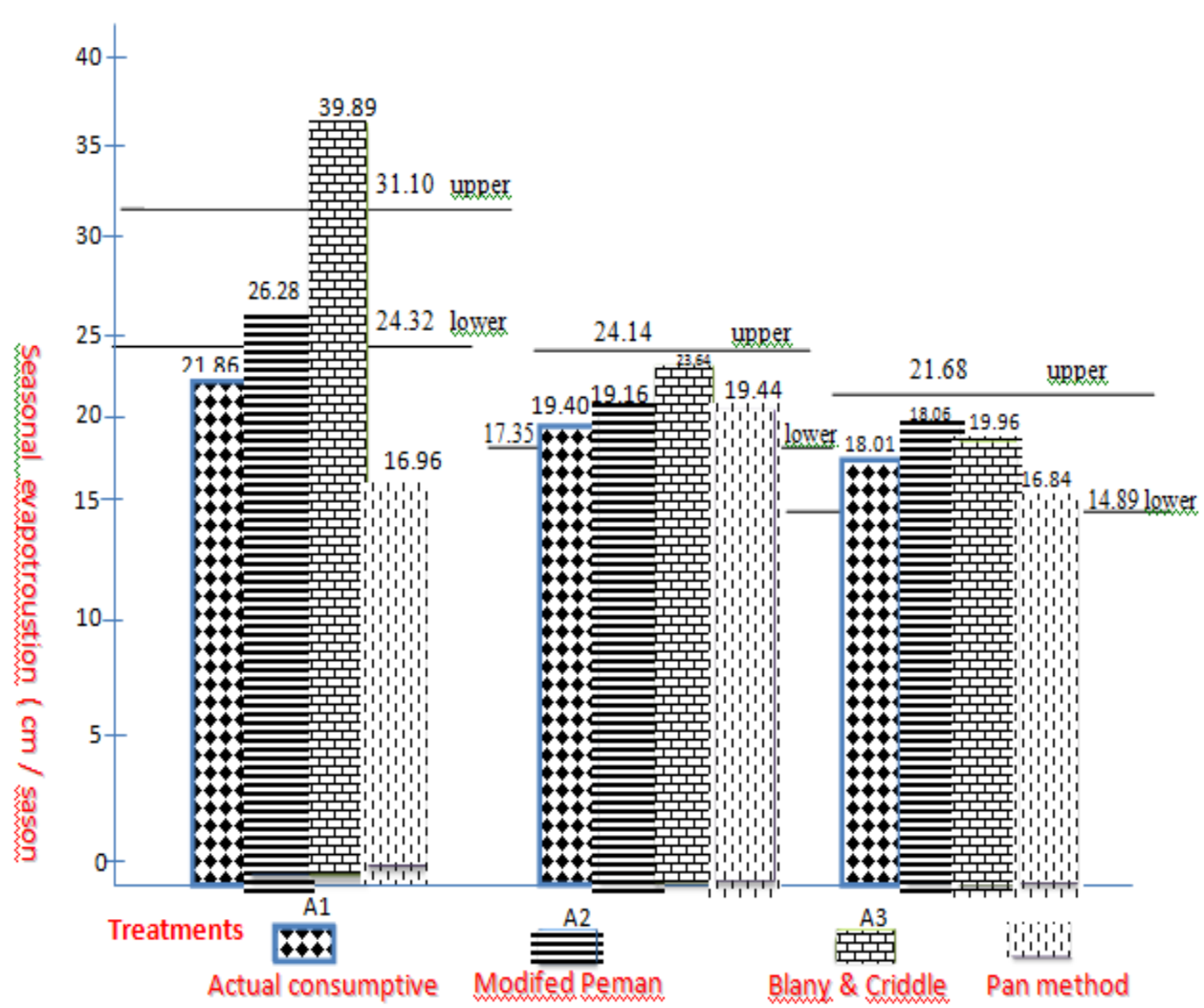

Fig ( 1 ) comparison between actual consumptive ( $\mathrm{cm} / \mathrm{season}$ ) and calculated exanotrous piration ( $\mathrm{cm}$ / season ) under irrigation regine $\mathrm{b}_{1}$ ( $20 \%$ depletion of A.W ) for aying crop. 
Response of quinoa crop for water stress and planting date in the middle Egypt

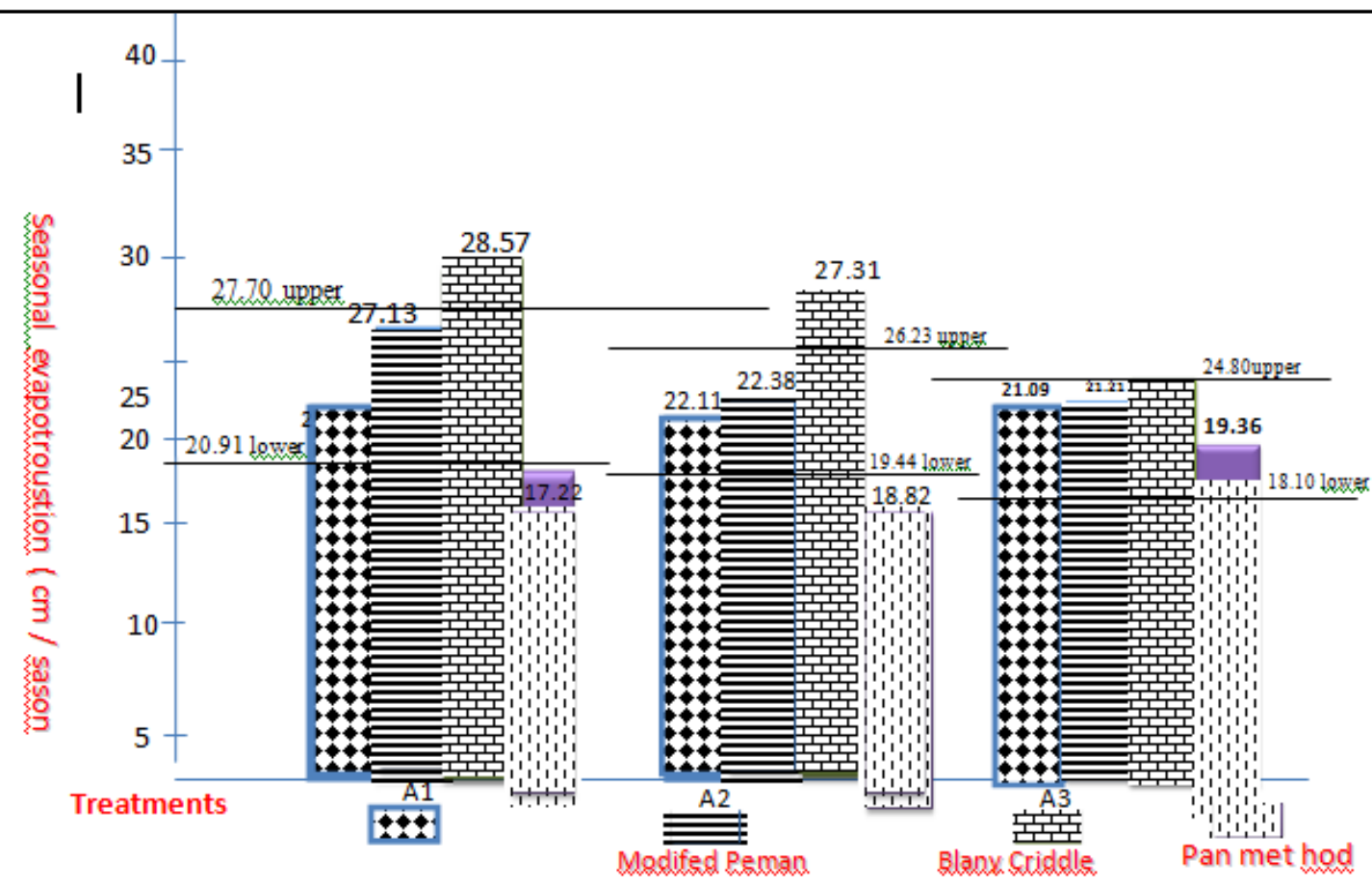

Actual consumptive

Fig ( 2 ). somparison between actual consumptive ( $\mathrm{cm} /$ season ) and calculated sxapotrouspiration ( $\mathrm{cm} /$ season ) under irrigation regime $\mathrm{b}_{2}(40 \%$ depletion of A.W $)$ for guing crop.

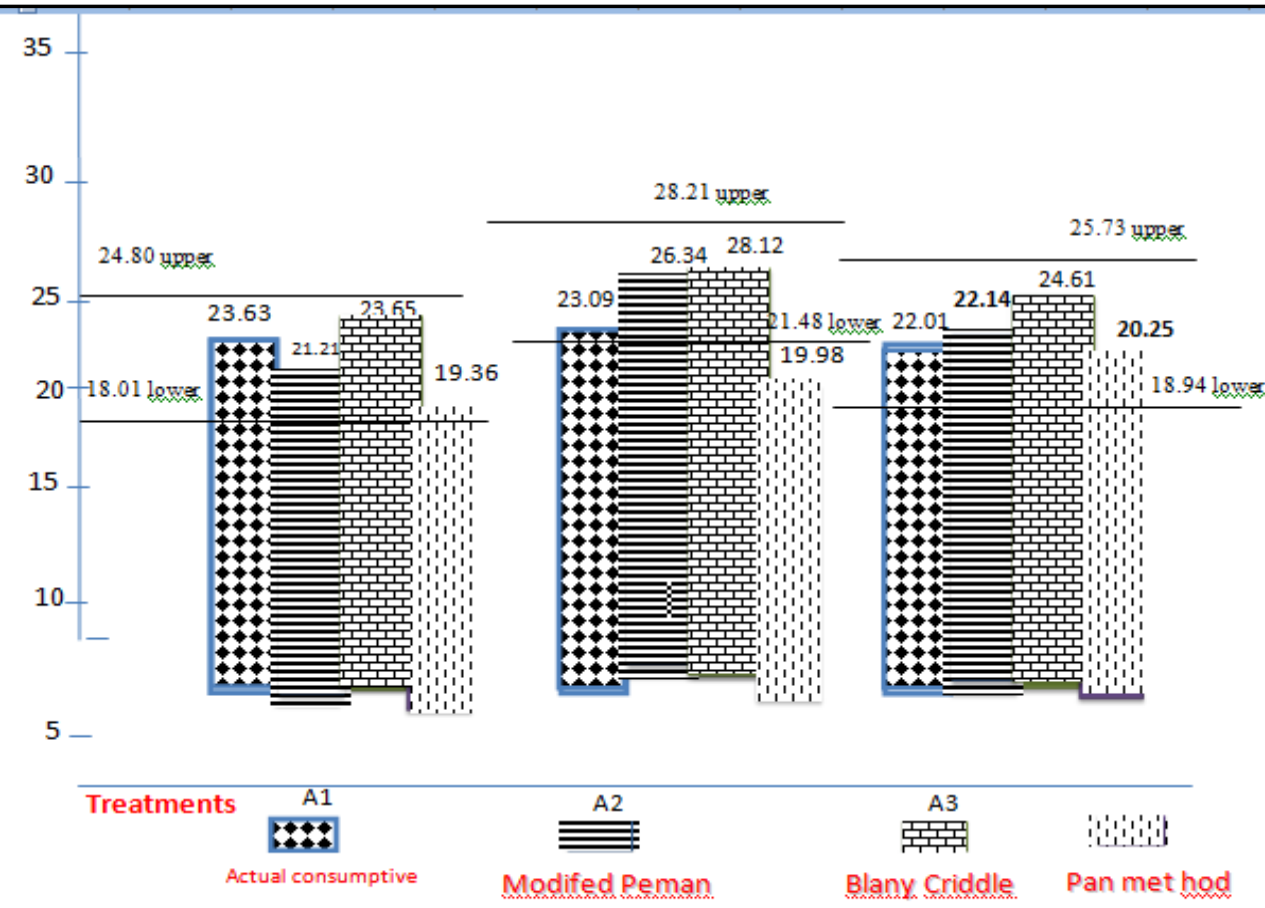

Fig (3.). comparison between actual consumptive ( $\mathrm{cm} /$ season ) and calculated exapotrous piration ( $\mathrm{cm}$ / season ) under irrigation regime $b_{3}(60 \%$ depletion of A.W ) for guing crop. 
Abdel-Rheem, H.A. et al.

Table (1) : Some soil - water characteristics for the experimental sites during the two growing seasons of Quinoa crop at different depths in 2000 and 2001 seasons.

\begin{tabular}{|c|c|c|c|c|c|c|c|}
\hline \multirow{3}{*}{$\begin{array}{r}\text { Depth } \\
(\mathrm{Cm})\end{array}$} & \multirow{3}{*}{$\begin{array}{c}\text { *Bulk } \\
\text { density } \\
\text { g/cm }\end{array}$} & \multicolumn{6}{|c|}{2000} \\
\hline & & \multicolumn{2}{|c|}{$* *$ Field capacity } & \multicolumn{2}{|c|}{$\begin{array}{c}\text { Wilting } \\
\text { point }\end{array}$} & \multicolumn{2}{|c|}{$\begin{array}{c}* * * \text { Available } \\
\text { Water }\end{array}$} \\
\hline & & $\%$ & $\mathbf{C m}$ & $\%$ & $\mathrm{Cm}$ & $\%$ & $\overline{\mathrm{Cm}}$ \\
\hline $0-15$ & 1.19 & 43.4 & 7.75 & 20.35 & 3.63 & 23.05 & 2.13 \\
\hline $15-30$ & 1.24 & 37.90 & 7.05 & 17.75 & 3.30 & 21.95 & 3.75 \\
\hline $30-45$ & 1.28 & 35.15 & 6.82 & 16.25 & 3.12 & 18.9 & 3.70 \\
\hline 45.60 & 1.37 & 31.99 & 6.33 & 15.5 & 3.19 & 16.49 & 3.14 \\
\hline Average & 1.27 & 37.2 & & 18.2 & & & \\
\hline
\end{tabular}

*Bulk density it was determined by using the undistributed core samples according to Kluke (1986) .

**Field capacity (f.c\%) it was determined by field method according to ( Black ,1965) .

***Available water (A.W) it was calculated as the difference between the F.C. and P.W.P .

Table ( 2 ) : The average values of temperature degree $(\dot{C})$ relative humidity $(\%)$, sun shine (hours/ day), wind speed (kg/ day) and evaporation rate $(\mathrm{mm} / \mathrm{day})$ for both growing seasons under studied .

\begin{tabular}{|c|c|c|c|c|c|c|c|c|c|}
\hline \multirow[t]{2}{*}{ Month } & \multicolumn{3}{|c|}{ Temperature $(\dot{C})$} & \multicolumn{3}{|c|}{ Relative humidity ( \%) } & \multirow{2}{*}{$\begin{array}{c}\begin{array}{c}\text { Sun shine } \\
\text { ( hours/ } \\
\%)\end{array} \\
\end{array}$} & \multirow{2}{*}{$\begin{array}{c}\text { Wind } \\
\text { speed } \\
\text { Kg/day }\end{array}$} & \multirow{2}{*}{$\begin{array}{c}\text { Evaporation } \\
(\mathrm{mm} / \text { day })\end{array}$} \\
\hline & $\max$ & $\min$ & average & $\max$ & $\min$ & average & & & \\
\hline November & 25.85 & 19.03 & 22.44 & 100 & 16.2 & 58.1 & 11.55 & 217.73 & 4.57 \\
\hline December & 20.5 & 6.7 & 13.6 & 100 & 44 & 72 & 8.4 & 198.72 & 2.66 \\
\hline January & 26.2 & 5.24 & 15.72 & 100 & 48.5 & $\mathbf{7 4 . 2 5}$ & 8.3 & 263.52 & 3.53 \\
\hline February & 31.24 & 5.75 & 18.5 & 97.3 & 30.94 & 64.12 & 8.86 & 253.15 & 4.32 \\
\hline March & 36.16 & 8.89 & 22.52 & 97.39 & 25.85 & 61.62 & 9.69 & 285.78 & 6.33 \\
\hline April & 29.24 & 11.41 & 20.32 & 90.37 & 26.03 & 58.2 & 10.83 & 318.69 & 8.14 \\
\hline May & 36.41 & 17.94 & 27.17 & 73.48 & 15.9 & 44.69 & 11.47 & 203.4 & 12.22 \\
\hline
\end{tabular}

Table (3) : Effect of planting dates and irrigation regime on productively of Quinoa crop in both studied seasons .

\begin{tabular}{|c|c|c|c|c|}
\hline \multirow{3}{*}{ Treatments } & \multicolumn{3}{|c|}{ Total yield ( ton/ fed.) } & \multirow{3}{*}{ Mean } \\
\hline & \multicolumn{3}{|c|}{ Irrigation regime } & \\
\hline & $\mathbf{b}_{1}$ & $\mathbf{b}_{2}$ & $\mathbf{b}_{3}$ & \\
\hline $\mathbf{A}_{1}$ & 0.75 & 0.99 & 1.06 & 0.93 \\
\hline $\mathbf{A}_{2}$ & 0.655 & 0.77 & 0.905 & 0.775 \\
\hline $\mathbf{A}_{3}$ & 0.554 & 0.69 & 0.720 & 0.641 \\
\hline Mean & 0.653 & 0.83 & 0.893 & \\
\hline LSD 0.05 & \multicolumn{2}{|l|}{$A=0.007$} & $B=0.004$ & $\mathrm{AB}=\mathbf{0 . 0 0 8}$ \\
\hline
\end{tabular}

Where ;

$\mathrm{A}_{1}=$ Planting date at $25^{\text {th }}$ November

$\mathrm{A}_{2}=$ Planting date at $25^{\text {st }} \quad$ December

$\mathrm{b}_{1}=$ irrigation at a depletion of $20 \%$ from A. W

$\mathrm{A}_{3}=$ Planting date at $25^{\text {th }}$ January

$\mathrm{b}_{2}=$ irrigation at a depletion of $40 \%$ from A. W

$\mathrm{b}_{3=}$ irrigation at a depletion of $60 \%$ from $\mathrm{A}$. W 
Response of quinoa crop for water stress and planting date in the middle Egypt

Table ( 4 ) : Average actual water consumptive use values (daily, monthly and seasonal ) for Quinoa plants as affected by planting dates and irrigation regime in both studied seasons .

\begin{tabular}{|c|c|c|c|c|c|c|c|c|c|c|c|c|c|c|c|c|c|c|c|c|c|c|c|c|c|c|c|}
\hline & \multicolumn{9}{|c|}{$A_{1}$} & \multicolumn{9}{|c|}{$\mathrm{A}_{2}$} & \multicolumn{9}{|c|}{$\mathrm{A}_{3}$} \\
\hline & \multicolumn{3}{|c|}{$b_{1}$} & \multicolumn{3}{|c|}{$b_{2}$} & \multicolumn{3}{|c|}{$\mathbf{b}_{3}$} & \multicolumn{3}{|c|}{$\mathbf{b}_{1}$} & \multicolumn{3}{|c|}{$b_{2}$} & \multicolumn{3}{|c|}{$\mathbf{b}_{3}$} & \multicolumn{3}{|c|}{$\mathbf{b}_{1}$} & \multicolumn{3}{|c|}{$\mathbf{b}_{2}$} & \multicolumn{3}{|c|}{$\mathbf{b}_{3}$} \\
\hline & 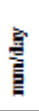 & 言 & $\begin{array}{l}\text { ह } \\
\text { z }\end{array}$ & 吝 & 吾 & 雍 & 吝 & 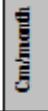 & 离 & 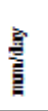 & 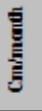 & 㤩 & 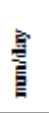 & 言 & 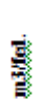 & 商 & है & 离 & 吝 & 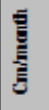 & 点 & 胥 & 吾 & 彔 & 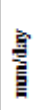 & 言 & $\begin{array}{l}\text { ह } \\
\text { w }\end{array}$ \\
\hline Nob. & $\stackrel{5}{2}$ & $\stackrel{\breve{g}}{=}$ & 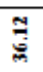 & $\frac{\pi}{2}$ & $\stackrel{\square}{\leftrightarrows}$ & $\mathbb{F}_{\tilde{\sim}}$ & 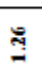 & $\stackrel{3}{8}$ & 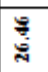 & . & . & . & . & . & . & . & . & . & . & . & . & . & . & . & . & . & . \\
\hline Dec. & $\underset{\text { J }}{\tilde{j}}$ & 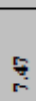 & $\begin{array}{l}\overrightarrow{0} \\
\frac{m}{m}\end{array}$ & 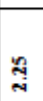 & స్ ప్ & בั & $\underset{\text { A }}{\bar{d}}$ & ڤ్ & 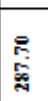 & $\stackrel{\Im}{ت}$ & $\underline{\underline{B}}$ & $\begin{array}{l}\text { \% } \\
\square\end{array}$ & $\stackrel{2}{2}$ & $\stackrel{\Xi}{\Xi}$ & $\approx$ & $\hat{\sigma}$ & $\stackrel{10}{=}$ & $\begin{array}{l}\bar{p} \\
m_{\infty}^{\infty}\end{array}$ & . & . & . & . & . & . & . & . & . \\
\hline Jan & $\underset{\pi}{5}$ & $\frac{n}{\infty}$ & 总 & $\overrightarrow{\mathrm{d}}$ & $\underset{m}{5}$ & 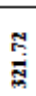 & 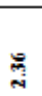 & लै & $\begin{array}{l}3 \\
\text { 芦 } \\
\text { 窇 }\end{array}$ & $\vec{n}$ & $\underset{2}{2}$ & 总 & $\stackrel{\tilde{A}}{\mathrm{~N}}$ & $\Xi$ & 竞 & $\underline{\Xi}$ & $\Xi$ & $\frac{\mathbb{Z}}{\mathbb{Z}}$ & $=$ & $\stackrel{\mathcal{E}}{\mathscr{z}}$ & 苨 & 3 & స్త్ & $\stackrel{\infty}{=}$ & $\stackrel{\mathbb{F}}{\mathrm{F}}$ & $\stackrel{\vec{p}}{=}$ & $\mid$ \\
\hline Feb & $\underset{\sim}{\Xi}$ & 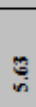 & 趈 & స్ & 5 & స్ర్స & $\underset{\mathrm{N}}{\overrightarrow{\mathrm{N}}}$ & $\overline{5}$ & 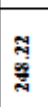 & $\underset{\sim}{n}$ & $\stackrel{3}{2}$ & 芯 & $\underset{\sim}{n}$ & $\mathrm{~m}$ & 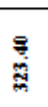 & 孚 & तु & 窎 & $\stackrel{\vec{n}}{\sim}$ & $\stackrel{3}{m}$ & 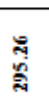 & के & ह & $\overrightarrow{\mathrm{g}}$ & 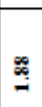 & 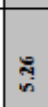 & : \\
\hline March & $\stackrel{\Xi}{=}$ & ถี & $\begin{array}{l}\overrightarrow{\vec{a}} \\
\overrightarrow{6}\end{array}$ & $\stackrel{7}{3}$ & 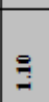 & త్త్ & ले & 5 & $\begin{array}{l}\vec{T} \\
\stackrel{5}{*}\end{array}$ & $\stackrel{m}{=}$ & $\vec{n}$ & 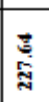 & $\stackrel{5}{-5}$ & $\frac{\infty}{n}$ & 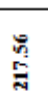 & $\underset{-}{2}$ & $\underset{0}{\Xi}$ & 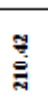 & $\stackrel{乛 乛}{\mathrm{i}}$ & $\underset{7}{\mathbb{2}}$ & $\stackrel{\tilde{F}}{\tilde{J}}$ & $\frac{10}{2}$ & की & 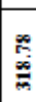 & 5 & 疋 & 卷 \\
\hline April & . & . & $\cdot$ & . & $\cdot$ & . & . & . & $\cdot$ & $\stackrel{\mathbb{S}}{=}$ & $\stackrel{2}{=}$ & 芯 & $\stackrel{n}{n}$ & తี & 离 & : & $\stackrel{\square}{\leftrightarrows}$ & $\stackrel{\text { tี }}{\text { కี }}$ & ت2 & Aี & 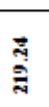 & تِّ & $\stackrel{\circ}{7}$ & 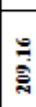 & 3 & 5 & 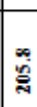 \\
\hline May & . & . & . & . & . & . & . & . & . & & . & & . & . & . & . & . & & $\stackrel{n}{=}$ & త్ & $\frac{\vec{n}}{n}$ & $\stackrel{n}{=}$ & 絗 & ఝू & $\stackrel{n}{=}$ & $\frac{5}{2}$ & 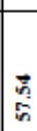 \\
\hline Total & & 5 & 迎 & & 足 & 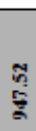 & & $\underset{\pi}{*}$ & ڤू. & & $\ddot{\sim}$ & 总 & & $\underset{\text { d }}{\bar{d}}$ & 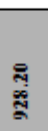 & & $\stackrel{\mathrm{g}}{\mathrm{g}}$ & $\overline{\bar{E}}$ & & $\underset{\mathbb{N}}{\Xi}$ & 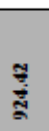 & & $\stackrel{\mathrm{N}}{\mathrm{d}}$ & 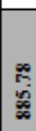 & & 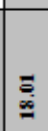 & 赵 \\
\hline
\end{tabular}

Table (5). Average seasonal actual water consumptive use ( $\mathrm{cm} / \mathrm{season})$ for corn crop plants as effected by planting dates and irrigation regime in both studied seasons .

\begin{tabular}{|l|l|l|l|l|}
\hline \multirow{3}{*}{ Planting dates } & \multicolumn{4}{l|}{ Seasonal actual water consumptive use (cm/season ) } \\
\cline { 2 - 5 } & \multicolumn{4}{|l|}{ Irrigation regime } \\
\cline { 2 - 5 } & $\mathbf{b}_{\mathbf{1}}$ & $\mathbf{b}_{\mathbf{2}}$ & $\mathbf{b}_{\mathbf{3}}$ & Average \\
\hline $\mathbf{A}_{\mathbf{1}}$ & 23.63 & 22.56 & 21.68 & 22.62 \\
\hline $\mathbf{A}_{\mathbf{2}}$ & 23.07 & 22.11 & 19.05 & 21.41 \\
\hline $\mathbf{A}_{\mathbf{3}}$ & 22.12 & 21.01 & 18.01 & 20.37 \\
\hline Average & 22.92 & 21.92 & 19.58 & 21.47 \\
\hline
\end{tabular}


Abdel-Rheem, H.A. et al.

Table (6): Average computed daily monthly, seasonal evapotranspiration $(\mathrm{mm}) \mathbf{E T}_{\mathrm{P}}$ and deviation percentage during both studied seasons .

\begin{tabular}{|c|c|c|c|c|c|c|c|c|c|c|c|c|c|c|c|c|c|c|}
\hline \multirow{2}{*}{\multicolumn{2}{|c|}{$\begin{array}{l}\text { Empirical } \\
\text { formulh }\end{array}$}} & \multicolumn{2}{|c|}{ Sorember } & \multicolumn{2}{|c|}{ Derember } & \multicolumn{2}{|c|}{ Janury } & \multicolumn{2}{|c|}{ February } & \multicolumn{2}{|c|}{ March } & \multicolumn{2}{|c|}{ April } & \multicolumn{2}{|l|}{ May } & \multicolumn{2}{|l|}{ Iotal } & \multirow{2}{*}{$\begin{array}{c}\text { Deriation } \\
\text { percentage } \\
\text { (96) }\end{array}$} \\
\hline & & Dais & $\begin{array}{l}\text { Morith } \\
\text { (mal) }\end{array}$ & $\begin{array}{l}\text { Doily } \\
\text { (nni) }\end{array}$ & $\begin{array}{l}\text { Minsty } \\
\text { (m) }\end{array}$ & $\begin{array}{l}\begin{array}{l}\text { Dels } \\
\text { (nd })\end{array} \\
\end{array}$ & $\begin{array}{l}\text { Vikath } \\
\text { fmni }\end{array}$ & $\begin{array}{l}\text { Duis } \\
\text { (min) }\end{array}$ & $\begin{array}{l}\text { Vhenth } \\
\text { (mal) }\end{array}$ & $\begin{array}{l}\text { Doris } \\
\text { fan }\end{array}$ & $\begin{array}{l}\text { Irafity } \\
\text { (end) }\end{array}$ & $\begin{array}{l}\text { Dhit } \\
\text { (men) }\end{array}$ & $\begin{array}{l}\text { Mentity } \\
\text { (mal) }\end{array}$ & $\begin{array}{l}\text { Doily } \\
\text { (nni) }\end{array}$ & $\begin{array}{l}\text { Mrafily } \\
\text { (nni) }\end{array}$ & $=$ & $=$ & \\
\hline \multirow{3}{*}{ At } & $\begin{array}{l}\text { Modified } \\
\text { Peaman }\end{array}$ & 6.99 & 3495 & 5.43 & 168.33 & 254 & 78.74 & 4.71 & 131.58 & 521 & 130.25 & - & - & - & - & 54415 & 54.41 & +597 \\
\hline & 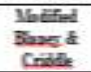 & 520 & 26.00 & 391 & 121.21 & 4.34 & 13454 & 491 & 137.45 & 590 & 1475 & - & - & - & - & 566.73 & 56.67 & -1454 \\
\hline & $\begin{array}{c}\text { Pan } \\
\text { method }\end{array}$ & 3.13 & 17.15 & 2.00 & 62.2 & 265 & 8215 & 3.34 & 9352 & 4.75 & 118.75 & - & - & - & - & 37359 & 3736 & 2451 \\
\hline \multicolumn{2}{|c|}{ Areragt } & - & - & & & & & & & & & & & & & 4948 & 49.48 & - \\
\hline \multirow{3}{*}{ A } & $\begin{array}{l}\text { Wodified } \\
\text { Peaman }\end{array}$ & - & - & 5.43 & 38.01 & 254 & 78.74 & 4.71 & 131.58 & 5.21 & 161.51 & 5.05 & 116.15 & & - & 52629 & 52.69 & 2.73 \\
\hline & $\begin{array}{l}\text { Nolined } \\
\text { Shase is } \\
\text { Croble }\end{array}$ & - & - & 391 & 2739 & 4.34 & 134.45 & 491 & 137.45 & 5900 & 182.90 & 598 & 19754 & & - & 619.74 & 6197 & +1452 \\
\hline & $\begin{array}{c}\text { Pan } \\
\text { method }\end{array}$ & - & - & 200 & 14.0 & 265 & 8215 & 334 & 9352 & 475 & 14725 & 610 & 14630 & & - & 4722 & 422 & -11.81 \\
\hline \multicolumn{2}{|c|}{ Arerage } & - & & - & - & & & & & & & & & & & 54197 & 5.11 & \\
\hline \multirow{3}{*}{ As } & $\begin{array}{l}\text { Modified } \\
\text { Peaman }\end{array}$ & - & - & - & - & 254 & 1778 & 4.71 & 131.58 & 521 & 161.51 & 5.15 & 151.50 & 8.65 & 70750 & 68027 & ff03 & +1.13 \\
\hline & 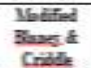 & - & - & - & - & 434 & 36.38 & 491 & 137.45 & 590 & 18290 & 598 & 179.4 & 715 & 171.60 & 701.76 & 72.17 & +3.49 \\
\hline & $\begin{array}{c}\text { Pan } \\
\text { method }\end{array}$ & - & - & - & - & 265 & 18.55 & 3.34 & 9352 & 4.75 & 14725 & 610 & 183.02 & 9.16 & 219.54 & 61216 & 6622 & 233 \\
\hline \multicolumn{2}{|c|}{ Arerngt } & - & & - & - & & & & & & & & & & & 678.96 & 6730 & \\
\hline
\end{tabular}

$-13-$

Table $(7)$ : The crop coefficient $\left(\mathbf{K c}=\mathbf{E T}_{\mathrm{a}} / \mathbf{E T}_{\mathrm{p}}\right)$ for different treatments for Quinoa crop $($ under irrigation regime $\left.b_{1}\right)$ in both studied seasons.

\begin{tabular}{|c|c|c|c|c|c|c|c|c|c|c|c|c|}
\hline \multirow{3}{*}{$\begin{array}{l}\text { Treat } \\
\text { ments } \\
\text { mont } \\
\text { h }\end{array}$} & \multicolumn{4}{|c|}{$\mathbf{A}_{1} \mathbf{b}_{1}$} & \multicolumn{4}{|c|}{$\mathbf{A}_{2} \mathbf{b}_{1}$} & \multicolumn{4}{|c|}{$\mathbf{A}_{\mathbf{3}} \mathbf{b}_{1}$} \\
\hline & \multicolumn{4}{|c|}{ Kc } & \multicolumn{4}{|c|}{ Kc } & \multicolumn{4}{|c|}{ Kc } \\
\hline & $\begin{array}{l}\text { Modifieied } \\
\text { panman }\end{array}$ & $\begin{array}{c}\text { Modified } \\
\text { Blaney \& } \\
\text { Criddle }\end{array}$ & $\begin{array}{c}\text { Pan } \\
\text { method }\end{array}$ & $\begin{array}{c}\text { (kc) } \\
\text { Average }\end{array}$ & $\begin{array}{c}\text { Modifieied } \\
\text { panman }\end{array}$ & $\begin{array}{c}\text { Modified } \\
\text { Blaney \& } \\
\text { Criddle }\end{array}$ & $\begin{array}{c}\text { Pan } \\
\text { method }\end{array}$ & $\begin{array}{c}\text { (kc) } \\
\text { Average }\end{array}$ & $\begin{array}{c}\text { Modifieied } \\
\text { panman }\end{array}$ & $\begin{array}{c}\text { Modified } \\
\text { Blaney \& } \\
\text { Criddle }\end{array}$ & $\begin{array}{c}\text { Pan } \\
\text { method }\end{array}$ & $\begin{array}{c}\text { (kc) } \\
\text { Average }\end{array}$ \\
\hline No. & 0.25 & 0.34 & 0.73 & 0.44 & - & - & - & & - & & - & - \\
\hline Dec. & 0.44 & 0.62 & 1.21 & 0.76 & 0.27 & $\begin{array}{c}0.38 \\
\end{array}$ & 0.75 & 0.47 & - & - & - & - \\
\hline Jan & 1.04 & 0.61 & 0.99 & 0.88 & 0.92 & 0.54 & 0.88 & 0.78 & 0.46 & 0.27 & 0.44 & 0.39 \\
\hline Feb. & 0.43 & 0.41 & 0.60 & 0.48 & 0.60 & $\begin{array}{l}0.58 \\
\end{array}$ & 0.85 & 0.68 & 0.53 & 0.51 & 0.75 & 0.60 \\
\hline Mar. & 0.12 & 0.10 & 0.13 & 0.12 & 0.34 & 0.30 & 0.37 & 0.34 & 0.48 & 0.42 & 0.52 & 0.47 \\
\hline Apr. & - & - & - & - & 0.12 & 0.10 & 0.10 & 0.11 & 0.34 & 0.29 & 0.29 & 0.31 \\
\hline May & - & - & - & - & - & - & - & - & 0.06 & $\begin{array}{l}0.07 \\
\end{array}$ & 0.05 & 0.06 \\
\hline Av. & 0.64 & 0.42 & 0.73 & 0.54 & 0.45 & 0.38 & 0.59 & 0.48 & 0.37 & 0.31 & 0.41 & 0.37 \\
\hline
\end{tabular}

Table $(8)$ : The crop coefficient $\left(\mathrm{Kc}=\mathrm{ET}_{\mathrm{a}} / \mathrm{ET}_{\mathrm{p}}\right)$ for different treatments for Quinoa crop ( under irrigation regime $b_{2}$ ) in both studied seasons.

\begin{tabular}{|c|c|c|c|c|c|c|c|c|c|c|c|c|}
\hline \multirow{3}{*}{$\begin{array}{c}\text { Treatments } \\
\text { month }\end{array}$} & \multicolumn{4}{|c|}{$\mathbf{A}_{1} \mathbf{b}_{2}$} & \multicolumn{4}{|c|}{$\overline{\mathbf{A}_{2} \mathbf{b}_{2}}$} & \multicolumn{4}{|c|}{$\mathbf{A}_{\mathbf{3}} \mathbf{b}_{\mathbf{2}}$} \\
\hline & \multicolumn{4}{|c|}{ Kc } & \multicolumn{4}{|c|}{ Kc } & \multicolumn{4}{|c|}{ Kc } \\
\hline & $\begin{array}{c}\text { Modifieied } \\
\text { panman }\end{array}$ & $\begin{array}{c}\text { Modified } \\
\text { Blaney } \\
\& \\
\text { Criddle }\end{array}$ & $\begin{array}{c}\text { Pan } \\
\text { method }\end{array}$ & $\begin{array}{c}\text { (kc) } \\
\text { Average }\end{array}$ & $\begin{array}{c}\text { Modifieied } \\
\text { panman }\end{array}$ & $\begin{array}{c}\text { Modified } \\
\text { Blaney } \\
\& \\
\text { Criddle }\end{array}$ & $\begin{array}{c}\text { Pan } \\
\text { method }\end{array}$ & $\begin{array}{c}\text { (kc) } \\
\text { Average }\end{array}$ & $\begin{array}{c}\text { Modifieied } \\
\text { panman }\end{array}$ & $\begin{array}{c}\text { Modified } \\
\text { Blaney } \\
\& \\
\text { Criddle }\end{array}$ & $\begin{array}{c}\text { Pan } \\
\text { method }\end{array}$ & $\begin{array}{c}\text { (kc) } \\
\text { Average }\end{array}$ \\
\hline No. & 0.19 & 0.25 & 0.39 & 0.28 & - & - & - & - & - & - & - & - \\
\hline Dec. & 0.41 & 0.57 & 1.12 & 0.70 & 0.26 & 0.36 & 0.71 & 0.44 & - & - & - & - \\
\hline Jan & 0.97 & 0.57 & 0.93 & 0.82 & 0.89 & 0.52 & 0.85 & 0.75 & 0.44 & 0.26 & 0.43 & 0.38 \\
\hline Feb. & 0.45 & 0.45 & 0.66 & 0.52 & 0.58 & 0.56 & 0.82 & 0.65 & 0.51 & 0.49 & 0.71 & 0.57 \\
\hline Mar. & 0.08 & 0.07 & 0.09 & 0.08 & 0.32 & 0.28 & 0.35 & 0.32 & 0.47 & 0.41 & 0.52 & 0.47 \\
\hline Apr. & - & - & - & & 0.1 & 0.09 & 0.09 & 0.09 & 0.33 & 0.28 & 0.27 & 0.29 \\
\hline May & - & - & -- & & - & & & & 0.04 & 0.06 & 0.05 & 0.05 \\
\hline Average & 0.42 & 0.38 & 0.64 & 0.48 & 0.43 & 0.36 & 0.59 & 0.45 & 0.36 & 0.30 & 0.40 & 0.35 \\
\hline
\end{tabular}


Table (9) : The crop coefficient ( $\mathrm{Kc}=\mathbf{E T}_{\mathrm{a}} / \mathbf{E T} \mathrm{T}_{\mathrm{p}}$ ) for different treatments for Quinoa crop ( under irrigation regime $\left.b_{3}\right)$ in both studied seasons.

\begin{tabular}{|c|c|c|c|c|c|c|c|c|c|c|c|c|}
\hline \multirow{3}{*}{$\begin{array}{c}\text { Treatments } \\
\text { month }\end{array}$} & \multicolumn{4}{|c|}{$\overline{\mathbf{A}_{1} \mathbf{b}_{3}}$} & \multicolumn{4}{|c|}{$\overline{\mathbf{A}_{2} \mathbf{b}_{3}}$} & \multicolumn{4}{|c|}{$\overline{\mathbf{A}_{\mathbf{3}} \mathbf{b}_{3}}$} \\
\hline & \multicolumn{4}{|c|}{ Kc } & \multicolumn{4}{|c|}{ Kc } & \multicolumn{4}{|c|}{ Kc } \\
\hline & $\begin{array}{c}\text { Modifi } \\
\text { eied } \\
\text { panma } \\
\text { n }\end{array}$ & $\begin{array}{c}\text { Modified } \\
\text { Blaney \& } \\
\text { Criddle }\end{array}$ & $\begin{array}{c}\text { Pan } \\
\text { method }\end{array}$ & $\begin{array}{c}\text { (kc) } \\
\text { Average }\end{array}$ & $\begin{array}{c}\text { Modifieied } \\
\text { panman }\end{array}$ & $\begin{array}{c}\text { Modified } \\
\text { Blaney \& } \\
\text { Criddle }\end{array}$ & $\begin{array}{c}\text { Pan } \\
\text { method }\end{array}$ & $\begin{array}{c}\text { (kc) } \\
\text { Average }\end{array}$ & $\begin{array}{c}\text { Modifieied } \\
\text { panman }\end{array}$ & $\begin{array}{c}\text { Modified } \\
\text { Blaney \& } \\
\text { Criddle }\end{array}$ & $\begin{array}{c}\text { Pan } \\
\text { method }\end{array}$ & $\begin{array}{c}\text { (kc) } \\
\text { Average }\end{array}$ \\
\hline No. & 0.18 & 0.24 & 0.38 & 0.27 & - & - & - & & - & - & - & - \\
\hline Dec. & 0.41 & 0.57 & 1.10 & 0.69 & 0.07 & 0.24 & 0.47 & 0.26 & - & - & - & - \\
\hline Jan & 0.93 & 0.54 & 0.91 & 0.79 & 0.76 & 0.45 & 0.73 & 0.65 & 0.30 & 0.18 & 0.29 & 0.26 \\
\hline Feb. & 0.45 & 0.43 & 0.63 & 0.50 & 0.48 & 0.46 & 0.67 & 0.54 & 0.40 & 0.38 & 0.56 & 0.45 \\
\hline Mar. & 0.07 & 0.07 & 0.08 & 0.07 & 0.31 & 0.27 & 0.34 & 0.31 & 0.37 & 0.32 & 0.40 & 0.36 \\
\hline Apr. & - & & & & 0.09 & 0.08 & 0.07 & 0.08 & 0.32 & 0.27 & 0.27 & 0.29 \\
\hline May & - & & & & & & & & 0.07 & 0.08 & 0.06 & 0.07 \\
\hline Average & 0.41 & 0.37 & 0.62 & 0.47 & 0.34 & 0.30 & 0.46 & 0.37 & 0.29 & 0.25 & 0.32 & 0.29 \\
\hline
\end{tabular}

Table (10) : The Average calculated monthly evapotranspiration ( Kc average x ETp ) mm / month, $\mathrm{mm} / \mathrm{season}$ and $\mathrm{cm} / \mathrm{season}$ (under irrigation regime $b_{1}$ ) for different treatments for Quinoa crop in both studied seasons .

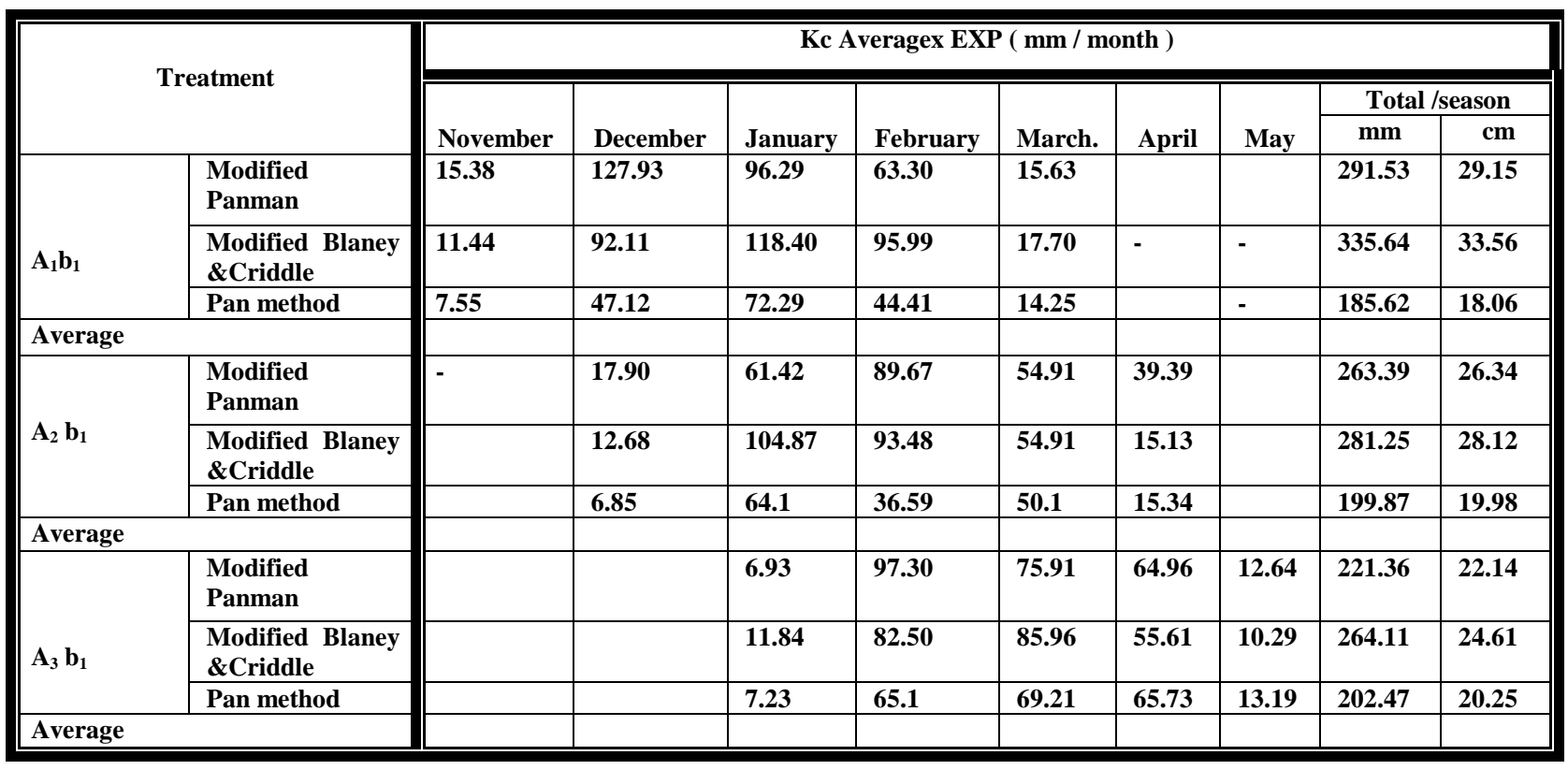


Abdel-Rheem, H.A. et al.

Table (11) : The Average calculated monthly evapotranspiration ( Kc average x ETp ) mm / month, $\mathrm{mm} / \mathrm{season}$ and $\mathrm{cm} / \mathrm{season}$ (under irrigation regime $b_{2}$ ) for different treatments for Quinoa crop in both studied seasons .

\begin{tabular}{|c|c|c|c|c|c|c|c|c|c|c|}
\hline \multirow{3}{*}{\multicolumn{2}{|c|}{ Treatment }} & \multicolumn{9}{|c|}{ "Kc Averagex EXP ( mm / month ) } \\
\hline & & \multirow[b]{2}{*}{ November } & \multirow[b]{2}{*}{ December } & \multirow[b]{2}{*}{ January } & \multirow[b]{2}{*}{ February } & \multirow[b]{2}{*}{ March. } & \multirow[b]{2}{*}{ April } & \multirow[b]{2}{*}{ May } & \multicolumn{2}{|c|}{ Total/season } \\
\hline & & & & & & & & & $\mathbf{m m}$ & cm \\
\hline \multirow{3}{*}{$\mathbf{A}_{1} \mathbf{b}_{2}$} & $\begin{array}{l}\text { Modified } \\
\text { Panman }\end{array}$ & 9.79 & 117.83 & 64.66 & 86.07 & 10.42 & - & - & 271.27 & 27.13 \\
\hline & $\begin{array}{l}\text { Modified } \\
\text { Blaney } \\
\text { \&Criddle } \\
\end{array}$ & 7.28 & 84.85 & 110.32 & 71.84 & 11.80 & - & -- & 285.73 & 28.57 \\
\hline & $\begin{array}{l}\text { Pan } \\
\text { method }\end{array}$ & 4.80 & 43.40 & 67.36 & 74.17 & 9.50 & - & - & 172.23 & 17.22 \\
\hline \multicolumn{11}{|c|}{ Average } \\
\hline \multirow{3}{*}{$\begin{array}{l}\mathbf{A}_{2} \\
\mathbf{b}_{2}\end{array}$} & $\begin{array}{l}\text { Modified } \\
\text { Panman }\end{array}$ & - & 16.94 & 59.05 & 85.72 & 51.86 & 10.54 & & 223.84 & 22.38 \\
\hline & $\begin{array}{l}\text { Modified } \\
\text { Blaney } \\
\text { \&Criddle }\end{array}$ & & 12.04 & 100.83 & 89.63 & 58.53 & 12.37 & & 273.13 & 27.31 \\
\hline & $\begin{array}{l}\text { Pan } \\
\text { method }\end{array}$ & & 6.18 & 61.16 & 60.86 & 14.12 & 12.63 & & 188.22 & 18.82 \\
\hline \multicolumn{11}{|c|}{ Average } \\
\hline \multirow{3}{*}{$\begin{array}{l}\mathbf{A}_{3} \\
\mathbf{b}_{2}\end{array}$} & $\begin{array}{l}\text { Modified } \\
\text { Panman }\end{array}$ & & & 6.67 & 75.17 & 75.91 & 43.93 & 10.38 & 212.15 & 21.21 \\
\hline & $\begin{array}{l}\text { Modified } \\
\text { Blaney } \\
\text { \&Criddle } \\
\end{array}$ & & & 11.54 & 87.36 & 85.96 & 52.03 & 8.58 & 236.47 & 23.65 \\
\hline & $\begin{array}{l}\text { Pan } \\
\text { method }\end{array}$ & & & 7.05 & 53.30 & 69.21 & 53.07 & 10.99 & 193.62 & 19.36 \\
\hline \multicolumn{2}{|c|}{ Average } & & & & & & & & & \\
\hline
\end{tabular}

(12): The Average calculated monthly evapotranspiration ( Kc average $\mathbf{x}$ ETp ) $\mathrm{mm} / \mathrm{month}$, $\mathrm{mm} / \mathrm{season}$ and $\mathrm{cm} / \mathrm{season}$ ( under irrigation regime $\mathrm{b}_{3}$ ) for different treatments for Quinoa crop in both studied seasons .

\begin{tabular}{|c|c|c|c|c|c|c|c|c|c|c|}
\hline \multirow{3}{*}{\multicolumn{2}{|c|}{ Treatment }} & \multicolumn{9}{|c|}{ Kc Averagex EXP ( mm / month ) } \\
\hline & & \multirow[b]{2}{*}{ November } & \multirow[b]{2}{*}{ December } & \multirow[b]{2}{*}{ January } & \multirow[b]{2}{*}{ February } & \multirow[b]{2}{*}{ March. } & \multirow[b]{2}{*}{ April } & \multirow[b]{2}{*}{ May } & \multicolumn{2}{|c|}{ Total /season } \\
\hline & & & & & & & & & $\mathbf{m m}$ & cm \\
\hline \multirow{3}{*}{$\mathbf{A}_{1} \mathbf{b}_{3}$} & $\begin{array}{l}\text { Modified } \\
\text { Panman }\end{array}$ & 9.44 & 116.14 & 62.20 & 65.49 & 9.12 & - & - & 262.84 & 26.28 \\
\hline & $\begin{array}{l}\text { Modified } \\
\text { Blaney } \\
\text { \&Criddle } \\
\end{array}$ & 7.02 & 83.63 & 106.29 & 86.74 & 103.25 & - & - & 386.93 & 36.89 \\
\hline & Pan method & 4.63 & 42.87 & 64.89 & 46.26 & 8.31 & & & 166.78 & 16.96 \\
\hline \multicolumn{11}{|c|}{ Average } \\
\hline \multirow{3}{*}{$\mathbf{A}_{2} \mathbf{b}_{3}$} & $\begin{array}{l}\text { Modified } \\
\text { Panman }\end{array}$ & - & 9.90 & 51.18 & 71.21 & $\mathbf{5 0 . 0 7}$ & 9.29 & - & 192.65 & 19.16 \\
\hline & $\begin{array}{l}\text { Modified } \\
\text { Blaney } \\
\text { \&Criddle } \\
\end{array}$ & - & 7.12 & 87.4 & 74.23 & 56.70 & 11 & & 263.45 & 23.64 \\
\hline & Pan method & & 3.64 & 53.40 & 50.50 & 45.65 & 11.22 & & 164.41 & 16.44 \\
\hline \multicolumn{11}{|c|}{ Average } \\
\hline \multirow{3}{*}{$\mathbf{A}_{\mathbf{3}} \mathbf{b}_{3}$} & $\begin{array}{l}\text { Modified } \\
\text { Panman } \\
\end{array}$ & - & - & 4.62 & 59.34 & 58.14 & 43.93 & 14.53 & 180.56 & 18.06 \\
\hline & $\begin{array}{l}\text { Modified } \\
\text { Blaney } \\
\text { \&Criddle } \\
\end{array}$ & - & - & 7.90 & 61.87 & 65.84 & 52.03 & 12.01 & 199.65 & 19.96 \\
\hline & Pan method & - & - & 4.82 & 42.08 & 53.01 & 53.07 & 15.39 & 186.37 & 16.84 \\
\hline Avera & & & & & & & & & & \\
\hline
\end{tabular}


Table ( 13 ) : Comparison between the actual consumptive use ( $\mathrm{cm} /$ season for two seasons ) and calculated evaportanspiratio ( $\mathrm{cm} /$ season for both seasons ) for different treatments for Quinoa crop (under irrigation regime $b_{1}$ ).

\begin{tabular}{|c|c|c|c|}
\hline \multirow{3}{*}{ Treatments } & \multicolumn{3}{|c|}{$\begin{array}{l}\text { Average of actual water consumptive use }(\mathrm{cm} / \text { season for both growing } \\
\text { seasons ) }\end{array}$} \\
\hline & $\begin{array}{c}A_{1} \\
23.63\end{array}$ & $\begin{array}{l}A_{2} \\
23.09\end{array}$ & $\begin{array}{l}A_{3} \\
22.01\end{array}$ \\
\hline & \multicolumn{3}{|c|}{ Calculated evapotranspiration ( Kc average ETp) } \\
\hline Modified Penman & 21.21 & 26.34 & 22.14 \\
\hline Modified Blaney \& Criddle & 23.65 & 28.12 & 24.61 \\
\hline Pan method & 19.36 & 19.98 & 20.25 \\
\hline Average & 21.41 & 24.81 & 22.33 \\
\hline Standard deviation & 2.15 & 4.28 & 2.19 \\
\hline Confidence limits $(95 \%)$ & 24.80 & 28.21 & 25.73 \\
\hline Confidence limits lower & 18.01 & 21.42 & 18.94 \\
\hline
\end{tabular}

Table (14) : Comparison between the actual consumptive use (cm / season for two seasons ) and calculated evaportanspiration $(\mathrm{cm} / \mathrm{season}$ for two seasons) for different treatments for Quinoa crop (under irrigation regime $\mathbf{b}_{2}$ ) .

\begin{tabular}{|c|c|c|c|c|}
\hline \multirow{3}{*}{\multicolumn{2}{|c|}{ Empirical formula }} & \multicolumn{3}{|c|}{$\begin{array}{l}\text { Average of actual water consumptive use }(\mathrm{cm} / \mathrm{season} \text { for both } \\
\text { growing seasons ) }\end{array}$} \\
\hline & & $A_{1} \quad 22.65$ & $\mathrm{~A}_{2} 22.11$ & $\mathbf{A}_{3} 21.09$ \\
\hline & & \multicolumn{3}{|c|}{ Calculated evapotranspiration $\left(\right.$ Kc average $\mathbf{E T}_{\mathrm{p}}$ ) } \\
\hline Modified Penman & 1 & 27.13 & 22.38 & 21.21 \\
\hline Modified Blaney \& Criddle & 2 & 28.57 & 27.31 & 23.65 \\
\hline Pan method & 3 & 17.22 & 18.82 & 19.36 \\
\hline Average & & 24.31 & 22.83 & 21.41 \\
\hline Standard deviation & & 6.18 & 4.26 & 2.15 \\
\hline Confidence limits $(95 \%) \quad \mathrm{U}$ & & 29.10 & 27.50 & 24.80 \\
\hline Confidence limits & & 20.91 & 19.44 & 18.01 \\
\hline
\end{tabular}

Table ( 15 ) : Comparison between the actual consumptive use ( $\mathrm{cm} /$ season for two seasons ) and calculated evaportanspiratio ( $\mathrm{cm} /$ season for both seasons ) for different treatments for Quinoa crop ( under irrigation regime $b_{3}$ ).

\begin{tabular}{|c|c|c|c|}
\hline \multirow{3}{*}{ Empirical formula } & \multicolumn{3}{|c|}{$\begin{array}{l}\text { Average of actual water consumptive use ( } \mathrm{cm} / \text { season } \\
\text { for both growing seasons ) }\end{array}$} \\
\hline & $\begin{array}{l}A_{1} \\
21.86\end{array}$ & $\begin{array}{l}A_{2} \\
19.40\end{array}$ & $\begin{array}{l}A_{3} \\
18.01\end{array}$ \\
\hline & \multicolumn{3}{|c|}{ Calculated evapotranspiration ( Kc average ETp) } \\
\hline Modified Penman & 26.28 & 19.16 & 18.06 \\
\hline Modified Blaney \& Criddle & 39.89 & 23.64 & 19.96 \\
\hline Pan method & 16.96 & 19.44 & 16.84 \\
\hline Average & 27.71 & 20.75 & 18.29 \\
\hline Standard deviation & 11.53 & 2.51 & 1.57 \\
\hline Confidence limits $(95 \%)$ Upper & 31.10 & 24.14 & 21.68 \\
\hline Confidence limits lower & 24.32 & 17.35 & 14.89 \\
\hline
\end{tabular}




\section{Conclusion}

Sowing dates on $25^{\text {th }}$ November with irrigate at a depletion of $60 \%$ from A.W . preferable and recommend for Quinoa crop in El Minia region to produce the highest yield with least possible amount of water. On the other hand this study indicate that the average values of potential evapotranspirations $\left(\mathrm{ET}_{\mathrm{cal}}\right)$ by modified Penman was nearest to actual consumptive use of Quinoa crop . So, we can recommend modified penman for calculating the potential evapationsiration Quinoa crop under El-Minia conditions and other corresponding conditions .

\section{REFERENCE}

Black,C.A.(1965).Methods of soil Analysis. Amer. Soc. Agro. Inc., Madison ,Wisconsin , USA.

Blaney, H.F. and W.D. Criddle (1955). Determining water in irrigated areas from climatologically and irrigation data, SCS-TP- 46, Soil conservation service, U.S. Department of Agriculture, Washington .

Doorehbos, J. and W.D. Pruit (1977). Guidelines for predicting crop water requirements . F.A.O. Irrigation and Drainage paper No.24, (revised )FAO, Rome ,Italy .

F.A.O. (1977). Crop water requirements. Irrigation and drainage paper 24. Food and Agriculture Organization for the united Nations, Rom revised, 1977 .

Galwey, N.W.(1992).The potential of quinoa as a multi-purpose crop for agricultural diversification ., Industrial Crops and Products ,1:101-106.

Geel, W. Van (1997). Quinoa in foodstuffs offers prospects , PAV Bulletin Akkerbouw ,1720 , November, Dutch .

Gesinski, K (2006). Evaluation of growth and flowering of Chenopodium quinoa Willd, under Polish conditions, Acts Agrobotanica, 59:487-496, Polskie Towarzystwo Botaniczyne ( Polish Botanical Society ),Warszawa, Poland .

Israelsen , O.W. and V.E. Hasan (1962). Irrigation principles and practices. $3^{\text {rd }}$ Edit. John willey \& Sons. Inc., New York .

Jacobsen , S.E.; A.Mujica and O.Stolen (1998) .Salt tolerance of quinoa during germination . Agronomia Tropical ( Maracay ), 48:359-366 .

Jacobsen , S.E.; B. Jornsgard ; J.L. Chrisriansen and O. Stolen (1999). Effect of harvest time, drying technique, temperature and light on the germination of quinoa (Chenopodium quinoa), Sci. and Technol., 27:937-944.

Jacobsen ,S.E.and A. Mujica (2001). Quinoa response to a biotic stress factors, Universidad National Agraria La Molina, Lima, Peru .

Jacobsen, S.E. and O. Stolen (1993).Quinoa -morphology, Phonology and prospects for its production as a new crop in Europe, European J. Agronomy, 2:19-29.

Martinez , E.A.; E.Veas ; C. Jorquera ; R. San Martin and P. Jara (2009). Re-introduction of quinoa into arid Chile: cultivation of two lowland races under extremely low irrigation. J. Agronomy and Crop Sci.,.195 : 1-10, Blackwell Publishing, Berlin , Germany .

Masoud, F.I.(1967).Water, Soil and relationship. New publication House, Alexandria. (In Arabic)

Nunez, N.; C.R. Jensen ; O. Stolen and R. Ortiz (1997).The influence of drought on leaf water relations and gas exchange at different growth stages in quinoa.Working group meeting, Wageningen, European Commission, DGXII, Science, Research and Development , COST,24-25 October 1997, 79-84, Netherlands .

Penman , H.L., (1961).Weather, plant and soil factors in hydrology Weather ,16:207 . 


\section{Response of quinoa crop for water stress and planting date in the middle Egypt}

Prado, F.E; C. Boero; M. Gallardo and J.A. Gonzalez (2000). Effect of $\mathrm{NaCl}$ ongemination , growth , and soluble sugar content in Chenopodium quinoa Willd. Seeds, Botanical Bull. Academia Sinica ,41:27-34.

Rijtma ,P.E.(1966).Transpiration and production of crops in relation to climate and irrigation. Institute form land and water management Research Holland (c.f. Mohamed A.F.M, 1981, Ph.D Thesis Fac. Agric .Alex. )

Snedecor ,G.V. and W.G. Cocharn (1980). Statistical method, sixth Edition, Iowa State Univ., Press ,Ames , Iowa ,USA .

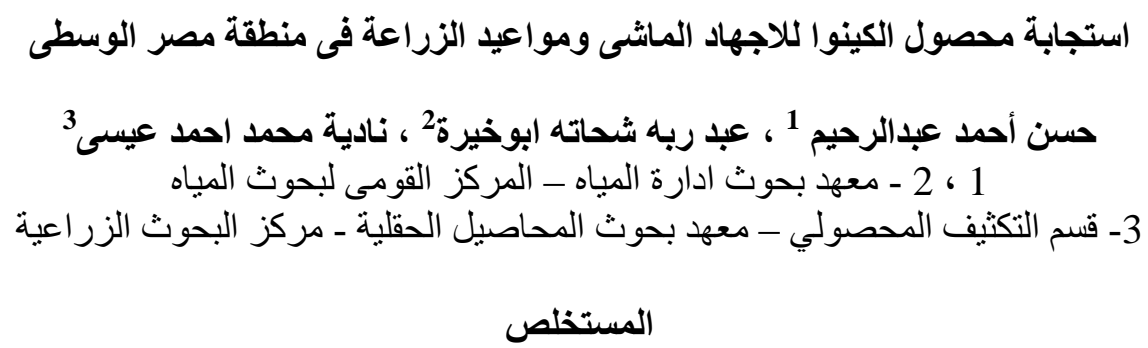

اجريت تجربتين حقليتين خلال المو اسم الثنتية لعامى 2013/2012 ، 2014/2013 م بمحطة مقننات رى ملوى البحثيه

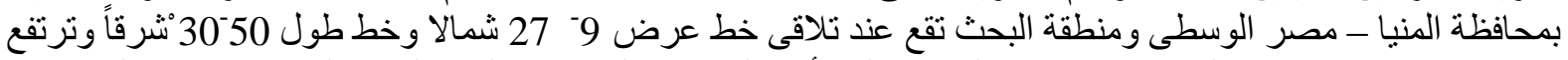

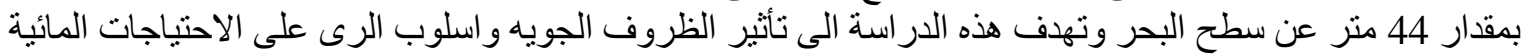

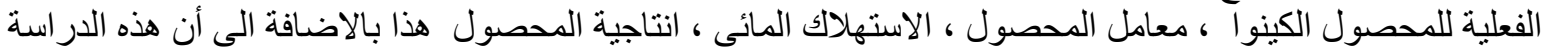

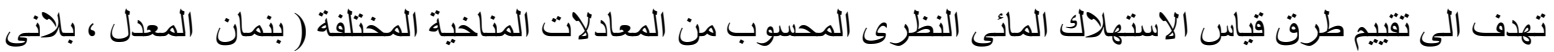

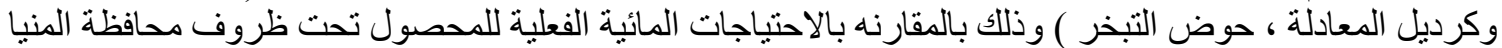

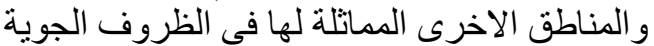

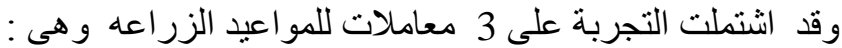
1/25:A3 12/25:A2 11/25: A1

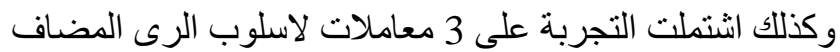

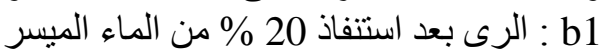

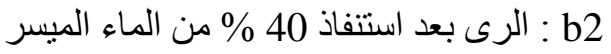

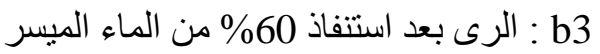

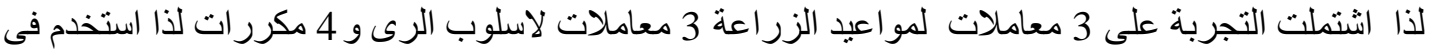

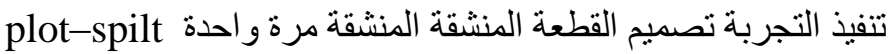

وفي ضوء ما سبق يمكن تلخيص النتائج المتحصل عليها كالتالى :

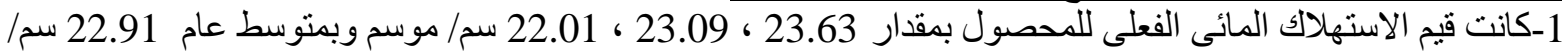
موسم للمعاملات A

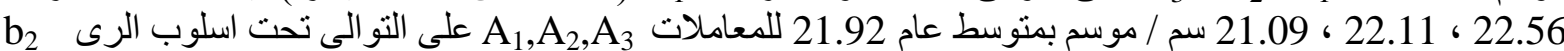

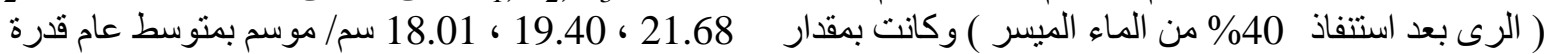

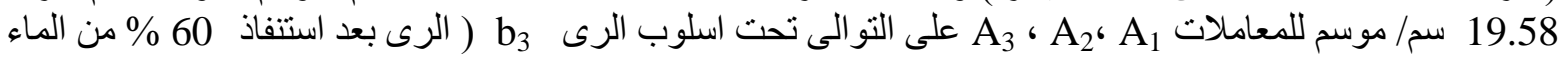
( الميسر )

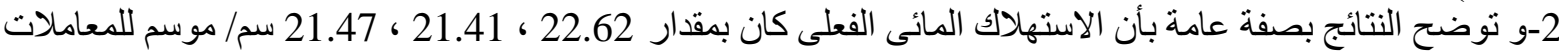

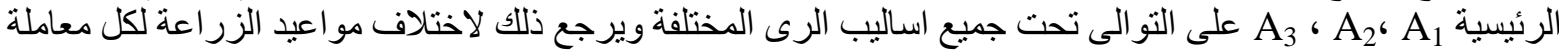

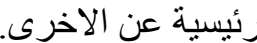

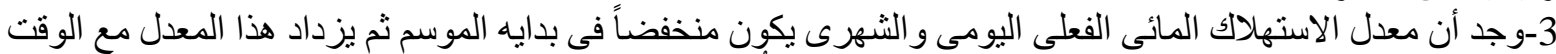

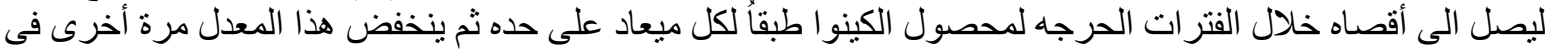

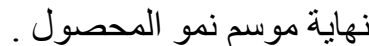
4- اعطيت المعاملة الاولى الزر اعة فى 11/25 اعلى انتاجية تحت جميع أساليب الرى المختلفة بزيادة قدر ها 23.17 \% ،

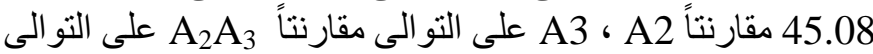


Abdel-Rheem, H.A. et al.

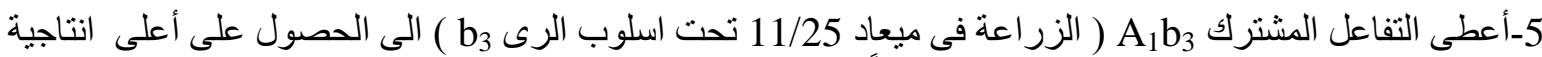

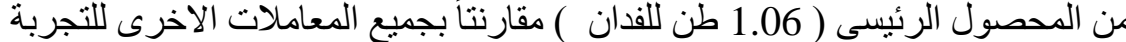

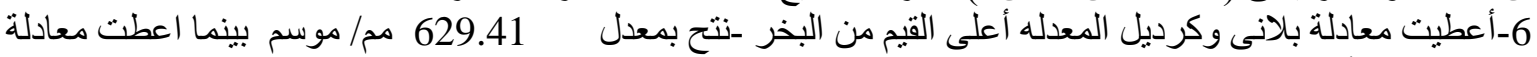
حوض التبخر أقل القيم للبخر -نتح ع بمقدار

7-كانت القيم الفعلبه للاستهلاك الفعلى (ETa

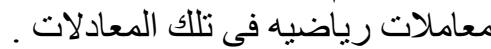

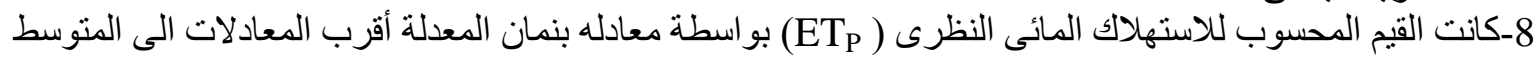

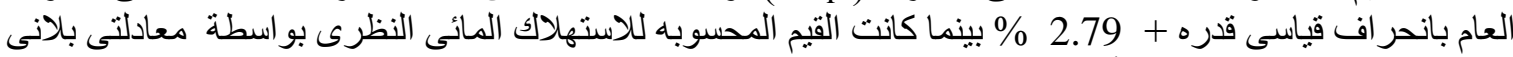

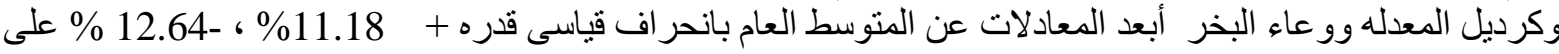

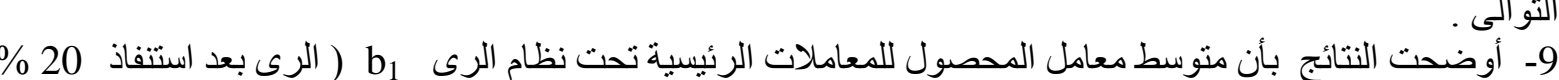

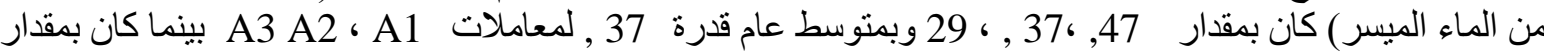

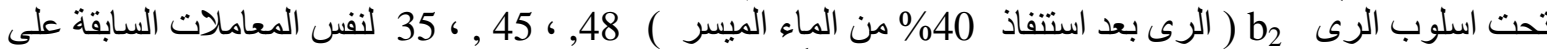

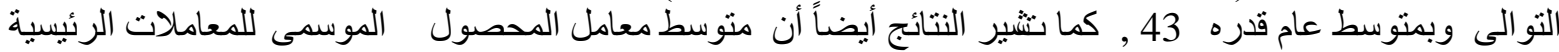

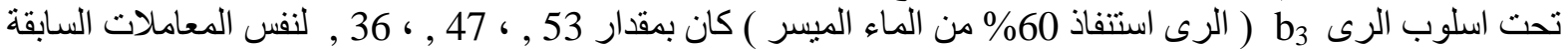
على التو الى وبمتوسط عام قدرة 0.45

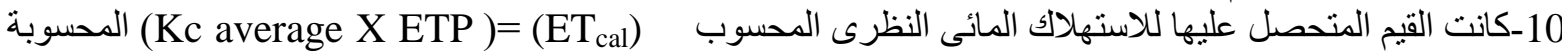

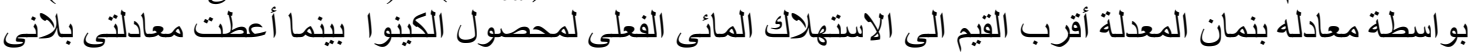

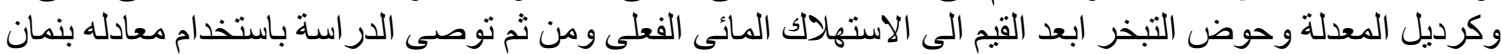

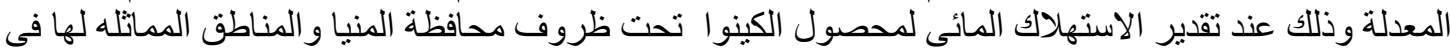
الظروف الجوية. 